\title{
Electrochemical characterization and application of azurin-modified gold electrodes for detection of superoxide
}

\author{
Sergey Shleev, Jonas Wetterö, Karl-Eric Magnusson and Tautgirdas Ruzgas
}

\section{Linköping University Post Print}

\section{Tweet}

N.B.: When citing this work, cite the original article.

Original Publication:

Sergey Shleev, Jonas Wetterö, Karl-Eric Magnusson and Tautgirdas Ruzgas, Electrochemical characterization and application of azurin-modified gold electrodes for detection of superoxide, 2006, Biosensors \& bioelectronics, (22), 2, 213-219.

http://dx.doi.org/10.1016/j.bios.2005.12.017

Copyright: Elsevier http://www.elsevier.com/

Postprint available at: Linköping University Electronic Press http://urn.kb.se/resolve?urn=urn:nbn:se:liu:diva-35118 


\title{
Electrochemical characterization and application of azurin modified gold electrodes for detection of superoxide
}

\author{
Sergey Shleev ${ }^{a^{*}}$, Jonas Wetterö ${ }^{\text {, }}$, Karl-Eric Magnusson ${ }^{\text {b }}$ and Tautgirdas Ruzgas ${ }^{\text {a }}$
}

${ }^{a}$ Biomedical Laboratory Science, Faculty of Health and Society, Malmö University, SE-205 06 Malmö, Sweden

${ }^{b}$ Division of Medical Microbiology, Department of Molecular and Clinical Medicine, Linköping University, SE-581 85 Linköping, Sweden

\begin{abstract}
The interaction of superoxide radicals with Pseudomonas aeruginosa azurin in solution and in adsorbed form was characterized using spectrophotometric and electrochemical techniques. It was determined that the rate constant for the reduction of azurin by superoxide ion in solution was about $10^{5} \mathrm{M}^{-1} \mathrm{~s}^{-1}$, being 2-3 times lower than the constant for cytochrome $c$. To prepare superoxide sensitive electrode azurin was immobilised on the surface of gold electrodes. Cyclic voltammetry measurements revealed that the best electron transfer between the protein and the electrode is realised at short-chain thiol, viz. 3,3'dithiobis(sulfosuccinimidylpropionate,)- (DTSSP-) modified gold. The formal potential of the redox protein on the DTSSP-modified electrode was found to be $380 \mathrm{mV} v s$. NHE being 100 $\mathrm{mV}$ more positive if compared to the standard redox potential of the $\mathrm{T} 1$ site of azurin from Pseudomonas aeruginosa. The heterogeneous electron transfer rate constant was determined to be in the range 2-6 s ${ }^{-1}$ for the azurin adsorbed on the DTSSP-modified gold electrodes.

Based on the electrochemical measurements the sensitivity of the biosensor towards superoxide was calculated to be $6.8 \cdot 10^{2} \mathrm{~A} \mathrm{~m}^{-2} \mathrm{M}^{-1}$. This value is about 12 times higher if compared to the sensitivity of the sensors based on cyt $c$ adsorbed on identical thiol layer, 2.5
\end{abstract}


times higher if compared to the sensitivity of the sensors based on cyt $c$ immobilized on a mixed-thiol (mercaptoundecanoic acid/mercaptoundecanol) modified gold electrodes, and it is twice lower if compared to the sensitivity of the multilayer cyt $c$ electrodes. The rate constant for the reduction of adsorbed azurin by superoxide ion was calculated and found to be $0.2 \cdot 10^{5}$ $\mathrm{M}^{-1} \mathrm{~s}^{-1}$, e.g. very close to the constant of immobilized cyt $c$. The influence of main interference substances, such as uric acid, $\mathrm{H}_{2} \mathrm{O}_{2}$, and dimethylsulfoxid on the signal of the sensor was investigated and was found negligible at concentrations below $10 \mu \mathrm{M}$.

Superoxide detection with azurin-modified electrodes was evaluated with the analyte originating from: i) an enzymatic xanthine oxidase (XOD) reaction, ii) a chemical reaction of potassium superoxide $\left(\mathrm{KO}_{2}\right)$ with water, and iii) from stimulated human neutrophil granulocytes. A signal from the biosensor was compared with the luminol-amplified chemiluminescence monitoring of reactive oxygen species from the neutrophils. The biosensor displayed a response to chemically and enzymatically generated superoxide, and adequate sensitivity to assess the biological response of stimulated human neutrophils.

Keywords: Azurin; Cytochrome c, Redox potential; T1 site; Gold electrode; Superoxide; Neutrophil granulocytes; Luminol-amplified chemiluminescence.

* Corresponding author. Tel.: +46-46-222-8191; fax: +46-46-222-4544

E-mail address: Sergey.Shleev@analykem.lu.se 


\section{Introduction:}

Free radicals are essential in human defence against infections. Among them, reactive oxygen intermediates (ROI) have also important non-bactericidal functions, i.e. in signal transduction, proliferation and thrombosis, and may be generated in a number of different cell types, including neutrophil granulocytes (Lander, 1997; Finkel, 1999; Stief, 2000). The formed ROI:s may be involved in the pathogenesis of inflammatory disorders and cancer, and they are difficult to detect directly due to their high reactivity and short lifetime (White et al., 1994; Amatore et al., 2000; Finkel and Holbrook, 2000). Hence, it is appealing to exploit the common advantages of electrochemical biosensors, such as real-time measurement, high sensitivity and selectivity for the detection of free radicals in biological samples.

The short-lived intermediate superoxide radical $\left(\mathrm{O}_{2}{ }^{--}\right)$is a primary ROI, which is potentially hostile to the host since it may exceed certain "antioxidant" levels locally in the tissue (White et al., 1994; Finkel and Holbrook, 2000). $\mathrm{O}_{2}{ }^{--}$results from the $1 \mathrm{e}^{-}$reduction of oxygen, and the determination of an absolute concentration is complicated due to spontaneous dismutation (Eq. 1):

$2 \mathrm{O}_{2}^{\bullet-}+2 \mathrm{H}^{+} \stackrel{k_{1}}{\rightarrow} \mathrm{O}_{2}+\mathrm{H}_{2} \mathrm{O}_{2}$

Several types of biosensors have been pioneered for the analysis of superoxide, namely biosensors based on superoxide dismutase (Lisdat et al., 1999; Yao et al., 2002) and cytochrome $c$ (McNeil et al., 1995; Campanella et al., 1997; Lisdat et al., 1999; Scheller et al., 1999; Barbacanne et al., 2000; Ge and Lisdat, 2002; McNeil and Manning, 2002). However, alternative biosensor designs would be appreciated if higher sensitivity, stability, and reproducibility could be provided.

The most popular electrochemical biosensors for superoxide detection are based on the direct detection of $\mathrm{O}_{2}{ }^{\bullet-}$ with cyt $c$-modified gold electrodes (Fig. 1), where cyt $c$ is the redox 
protein. In order to get direct electron transfer (DET) between the gold electrode and cyt $c$, short and long length thiols have been exploited (McNeil et al., 1995; Manning et al., 1998; Lisdat et al., 1999; Ge and Lisdat, 2002; McNeil and Manning, 2002). This way the reduction of cyt $c$ by $\mathrm{O}_{2}{ }^{--}$can be detected as a current due to a subsequent electrochemical oxidation of reduced protein at the electrode surface. The re-oxidation current of cyt $c$ is then proportional to the concentration of superoxide radical (Fig. 1). Analyses of the cyt $c$ biosensor suggest, that the sensitivity can be significantly improved by increasing the amount of redox protein on the electrode surface, or by replacing cyt $c$ with another protein showing higher selectivity towards $\mathrm{O}_{2}{ }^{\bullet-}$. The first strategy has been realized recently by a multilayer cyt $c$ sensor that display approximately five times higher sensitivity compared to the monolayer cyt $c$-modified gold electrode (Beissenhirtz et al., 2004). The second alternative could be to use a redox protein fulfilling the following requirements: $(i)$ the value of the standard redox potential $\left(\mathrm{E}^{\circ \prime}\right)$ should be moderately positive (in the range between 200-300 $\mathrm{mV}$ vs. NHE) ensuring electrochemical oxidation of the immobilized protein, yet avoiding electrooxidation of interferences such as peroxide and uric acid, (ii) rapid electrochemical redox conversion (reversible electrochemistry) of the electrode-immobilized protein should be realised in order to avoid kinetic limitations of the biosensor sensitivity, (iii) the protein should have good reactivity towards free radicals, as well as (iv) have a high stability on the electrode surface.

The small copper proteins (azurin, plastocyanin, stellacyanin, amicyanin, and rusticyanin) are all involved in intermolecular electron transfer pathways (Kaim and Rall, 1996; Messerschmidt et al., 2001). They contain a type 1 copper centre (T1 site), which exhibits unique spectroscopic characteristics, including their intense blue colour associated with a strong absorption band in the visible region at $600 \mathrm{~nm}$. Obviously, some of them satisfy all of the above requirements for an alternative redox protein. First of all, the $\mathrm{E}^{\circ}$ values of the "blue" redox proteins have been shown to range between 184 to 680 vs. NHE (Reinhammar, 1972; Solomon et al., 1992; Kuznetsov et al., 1996; Gray et al., 2000; Zhang et 
al., 2002; Li et al., 2004; Pinho et al., 2004). Several publications describe pronounced and stable electrochemical signals, where "blue" redox proteins have been immobilized on different electrode surfaces (Armstrong et al., 1984, 1985, 1989, 2004; Buechi et al., 1992; Kuznetsov et al., 1996; Jeuken et al., 2000; Pinho et al., 2004). Finally, recently the sufficient antioxidant properties or pronounced interactions with ROI has also been shown for coppercontaining redox proteins (Kang, 1999; Kumari et al., 2000; Kondoh et al., 2001; Shishido et al., 2001). Thus, they are strong candidates for ROI sensitive biosensors (Fig. 1) and they have also been suggested for this application (Lisdat and Karube, 2002).

Azurin is one of the smallest $(14 \mathrm{kDa})$ and simplest "blue" redox proteins (Solomon et al., 1992; Jeuken et al., 2000). The redox transformation of the T1 site is caused by the reversible redox conversion of the copper ion from $\mathrm{Cu}^{3+}$ to $\mathrm{Cu}^{2+}$, and azurin belongs to the group of low redox potential copper proteins with $\mathrm{E}^{\circ \prime}$-values varying between 270 to $320 \mathrm{vs}$. NHE depending on the protein source (Solomon et al., 1992; Gray et al., 2000; Zhang et al., 2002; Pinho et al., 2004; Shleev et al., 2005). Azurin from Pseudomonas aeruginosa is commercially available, has a known protein sequence and crystal structure. Moreover, its spectral, electrochemical, and kinetic properties have been studied extensively (Brill et al., 1968; Soininen and Ellfolk, 1972; Van de Kamp et al., 1990; Nar et al., 1991; Solomon et al., 1992; Van Pouderoyen et al., 1997; Gray et al., 2000; Jeuken et al., 2002; Andolfi et al., 2004; Armstrong et al., 2004).

The objectives of this work were $(i)$ to design and characterize a superoxide sensitive biosensor based on azurin-modified gold electrodes, and (ii) to apply the novel biosensor for real-time in vitro measurements of superoxide release from the xanthine oxidase reaction, from the interaction of $\mathrm{KO}_{2}$ with water, and from isolated human neutrophils. 


\section{Materials and methods}

\subsection{Chemicals and buffers}

$\mathrm{Na}_{2} \mathrm{HPO}_{4}, \mathrm{KH}_{2} \mathrm{PO}_{4}, \mathrm{H}_{2} \mathrm{O}_{2}, \mathrm{CaCl}_{2}, \mathrm{MgSO}_{4}, \mathrm{NaCl}$, and $\mathrm{KCl}$ were obtained from Merck GmbH (Darmstadt, Germany). Xanthine, fMLF-peptide (fMLF), phorbol 12-myristate 13acetate (PMA), 5-amino-2,3-dihydro-1,4-phtalazinedione (luminol), potassium superoxide $\left(\mathrm{KO}_{2}\right)$, and dimethylsulfoxide (DMSO) were from Sigma (St. Louis, MO, USA). 3,3'dithiobis(sulfosuccinimidylpropionate) (DTSSP) was from Pierce Biotechnology (Chester, UK). 11- mercapto-1-undecanol (MU) and 11-mercaptoundecanoic acid (MUA) were obtained from Aldrich (Steinheim, Germany). Uric acid and glucose were from ICN Biomedical Inc. (Irvine, CA, USA). Absolute ethanol (99.7\%) was from Solveco Chemicals AB (Täby, Sweden). All water solutions were prepared using water (18 M $\Omega$ ) purified with a Milli-Q system (Millipore, Milford, CT, USA). The main buffers were phosphate buffer (100 $\mathrm{mM}$ sodium hydrogen phosphate, $100 \mathrm{mM}$ potassium dihydrogen phosphate; $\mathrm{pH}$ 7.4; $\mathrm{PBB}$ ), phosphate-buffered saline (10 $\mathrm{mM}$ sodium hydrogen phosphate, $10 \mathrm{mM}$ potassium dihydrogen phosphate and $0.15 \mathrm{M}$ sodium chloride, $\mathrm{pH}$ 7.3; PBS), and Krebs-Ringer phosphate buffer supplemented with $10 \mathrm{mM}$ glucose, $1.5 \mathrm{mM} \mathrm{MgSO}_{4}$ and $1.1 \mathrm{mM} \mathrm{CaCl}_{2}(\mathrm{pH}$ $7.3 ; \mathrm{KRG})$.

\subsection{Proteins}

P. aeruginosa azurin (MW $14.0 \mathrm{kDa}$ ), cytochrome $c$ (cyt $c$, MW $12.4 \mathrm{kDa}$ ) from horse heart, xanthine oxidase from bovine milk (XOD, Grade III, 1-2 units/mg, MW 300.0 kDa), and superoxide dismutase from bovine erythrocytes (SOD, 2500-7000 units/mg, MW 31.2 kDa) were from Sigma.

\subsection{Cells}


Peripheral human polymorphonuclear neutrophil granulocytes (neutrophils) were isolated from heparinized $(5 \mathrm{U} / \mathrm{mL})$ whole blood immediately following venipunture of apparently healthy non-medicated volunteers that had given informed consent before donation. The isolation procedure was originally outlined by Böyum (Böyum, 1968), and later optimized by others (Ferrante and Thong, 1980). Only $\mathrm{Ca}^{2+}$-free buffers and suitable plastic devices were used during the separation. Specifically, whole blood was carefully layered on top of a separation liquid consisting of one part of Lymphoprep (Nycomed Pharma AS, Oslo, Norway) layered over four parts of Polymorphprep (Nycomed Pharma AS) and centrifuged for 40 minutes at $480 \mathrm{x} g$ at room temperature. The upper band containing mononuclear cells was discarded and the lower band containing neutrophils was harvested. The separation liquid was washed off through 10 minutes at $480 \times \mathrm{g}$ in room tempered PBS. The erythrocyte contamination was then eliminated by brief hypotonic lysis in ice-cold distilled water followed by washing of the cells twice at $200 \mathrm{x} g$ at $4^{\circ} \mathrm{C}$ in $\mathrm{KRG}$. The isolated cells showed excellent viability, low platelet contamination and were counted in a Coulter Counter ZM Channelyser 256 (Coulter-Electronics Ltd., Luton, UK) and kept on melting ice until experiments were performed.

\subsection{Azurin-modified gold electrodes}

Azurin-modified gold disk electrodes (bare gold electrodes were from Bioanalytical Systems, West Lafayette, IN, USA) were used for electrochemical studies. The surface of the working gold electrode was first polished in DP-Suspension, and then was polished in alumina FF slurry $(0.25 \mathrm{~mm}$ and $0.1 \mathrm{~mm}$, respectively, Struers, Copenhagen, Denmark), rinsed in Millipore water, with 10 min sonications in between. The electrodes were then cycled 30 times in $0.5 \mathrm{M} \mathrm{H}_{2} \mathrm{SO}_{4}$, and kept in concentrated $\mathrm{H}_{2} \mathrm{SO}_{4}$.

Electrodes were modified with azurin in three different ways. In the first case azurin was adsorbed directly on the gold electrode through 3 hours of incubation of gold disk electrodes 
in $1 \mathrm{mg} / \mathrm{ml}$ azurin solution in PBS. The second approach was a short length thiol-modified (DTSSP) gold electrode, prepared by immersion of the clean gold electrode in $50 \mathrm{mM}$ DTSSP solution for $5 \mathrm{~min}$. After this treatment the electrode was incubated in $1 \mathrm{mg} / \mathrm{ml}$ azurin in PBS for 20 hours, rinsed with water, and kept in PBS for $0.5 \mathrm{~h}$ for stabilization (desorption of loosely bound protein). In the third case, a thiol layer from long carbon chain thiols (MUD+MUA) was immobilised on the surface of gold electrodes by self assembling according to Ge and Lisdat (Ge and Lisdat, 2002). After thiol modification the electrode was kept in $1 \mathrm{mg} / \mathrm{ml}$ azurin for 2 hours, rinsed with water, and kept in PBS for $0.5 \mathrm{~h}$ for stabilization before measurements. After stabilization of the electrodes for $0.5 \mathrm{~h}$ they were ready for use.

Azurin-modified electrodes were assessed by cyclic voltammetry. Cyclic voltammograms (CVs) of the protein-modified electrodes were recorded using a threeelectrode potentiostat (BAS CV-50W Electrochemical Analyzer with BAS CV-50W software v. 2.1, Bioanalytical Systems, West Lafayette, IN, USA) and one single-compartment $20 \mathrm{ml}$ electrochemical cell. Reference electrode was an $\mathrm{Hg}\left|\mathrm{Hg}_{2} \mathrm{Cl}_{2}\right| \mathrm{KCl}_{\text {sat }}(242 \mathrm{mV}$ vs. NHE), and a platinum wire served as counter electrode.

\subsection{Homogeneous superoxide reaction with cytochrome $c$ and azurin in solution}

Absorbance spectra of the proteins were recorded in PBB in the presence of $2 \mathrm{mM}$ xanthine using a spectrophotometer Ultrospec II Biochrom "LKB" (Bromma, Sweden). The reduction of cyt $c$ and azurin by $\mathrm{O}_{2}{ }^{--}$was realized by XOD reaction (Eq. 2). Kinetic experiments were performed in PBB with $2 \mathrm{mM}$ xanthine. The concentrations of both redox proteins were varied between 7.2 and $72 \mu \mathrm{M}$.

$$
\text { (hypo)xanthine }+\mathrm{O}_{2}+\mathrm{H}_{2} \mathrm{O} \underset{\text { XOD }}{\stackrel{k_{2}}{\rightarrow} \text { urate }}+\mathrm{O}_{2}^{\bullet-}
$$




\subsection{Detection of the superoxide radicals}

\subsubsection{Electrochemical detection}

Studies on superoxide generation in cell free systems were performed using the BAS CV-50W potentiostat. The potential of $+500 \mathrm{mV} v s$. NHE was applied to the azurin-modified electrode, and chronoamperometric curves from the electrodes were recorded. $\mathrm{O}_{2}{ }^{\bullet-}$ was generated by xanthine and XOD as previously described (Cooper et al., 1993), or by reaction of $\mathrm{KO}_{2}$ with water. This reaction (Eq. 3) proceeds spontaneously after injection of $\mathrm{KO}_{2}$ in DMSO into the buffer solution (Ge and Lisdat, 2002). In later case the distance between the point of $\mathrm{KO}_{2}$ injection and the azurin electrode was varied from $1 \mathrm{~mm}$ to $10 \mathrm{~mm}$.

$$
\mathrm{KO}_{2}+\mathrm{H}_{2} \mathrm{O} \rightarrow \mathrm{O}_{2}{ }^{\bullet-}+\mathrm{KOH}+\mathrm{H}^{+}
$$

The extracellular generation of superoxide from isolated neutrophils was recorded using the three-electrode potentiostat BAS CV-50W. The potential of $+500 \mathrm{mV}$ was applied on the azurin modified working electrodes, and chronoamperometric curves from the modified electrodes were recorded. For this purpose, a silver wire in PBS or KRG was used as a combined reference and counter electrodes.

\subsubsection{Luminol-amplified chemiluminescence}

The intra- and extracellular generation of ROI:s over time from isolated neutrophils was studied by luminol-amplified chemiluminescence in a six-channel Biolumat (LB 9505 C, Berthold Co., Wildbaden, Germany). Measurements were performed at $37^{\circ} \mathrm{C}$ in $\mathrm{KRG}$ with HRP ( $4 \mathrm{U} / \mathrm{ml})$, luminol $(20 \mu \mathrm{g} / \mathrm{ml})$ and cells with the final concentration from $1 \times 10^{6} / \mathrm{ml}$ to 2 $\mathrm{x} 10^{7} / \mathrm{ml}$. Stimulation of neutrophils was performed using different types of stimulators, such as fMLF $(0.1 \mu \mathrm{M})$ or PMA $(0.1 \mu \mathrm{M})$. Intracellular ROI:s were detected by substituting HRP with the scavenger - SOD $(200 \mathrm{U} / \mathrm{ml})$. Cell solution was equilibrated for 5 minutes at $37^{\circ} \mathrm{C}$ 
and simultaneously with the chemiluminescence assay the extracellular production of $\mathrm{O}_{2}{ }^{\bullet-}$ was recorded by the azurin-based biosensor in one of the Biolumat channels (no HRP or luminol present).

\section{Results and Discussion}

\subsection{Electrochemistry of azurin}

Azurin-modified gold disk electrodes for the detection of $\mathrm{O}_{2}{ }^{\bullet-}$ were developed and their application was examined. The measurement results and different characteristics relevant to the function of the electrodes are summarised and discussed below. In the following discussion a particular emphasis is devoted on the difference between the azurin electrodes and the biosensors for $\mathrm{O}_{2}{ }^{--}$based on cyt $c$.

A number of reports describing DET of azurin has been published, e.g., (Armstrong et al., 1984; Sakurai et al., 1996; Jeuken et al., 2000; Jeuken et al., 2002; Armstrong et al., 2004). Well-resolved cyclic voltammograms (CVs) were previously recorded with the midpoint potential, $\mathrm{E}_{\mathrm{m}}$, (taken as an average of the anodic and cathodic peak potentials) close

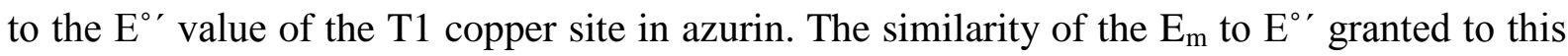
electrochemical method an acceptance that the redox potential for azurin and other small "blue" redox proteins, such as pseudoazurin, umecyanin, stellacyanin, plantacyanin, and plastocyanin can be determined by simple CV measurement (e.g., (Berezin et al., 1978;

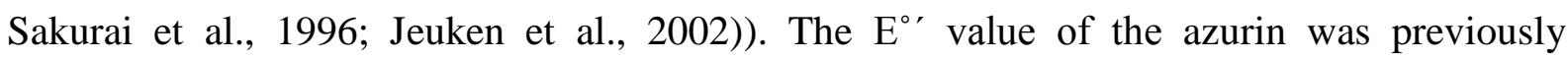
estimated to be close to $300 \mathrm{mV}$ vs. NHE (Solomon et al., 1992; Gray et al., 2000; Li et al., 2004; Pinho et al., 2004).

Fig. 2 shows CVs of azurin immobilized on the surface of gold electrodes. As can be seen in Fig. 2, stable and quasi-reversible electrochemical redox cycling of the T1 site in the protein is obtained for azurin immobilised by a short thiol DTSSP. $\mathrm{E}_{\mathrm{m}}$ is equal to $380 \mathrm{mV} v s$. NHE being close to the $\mathrm{E}^{\circ \prime}$ value $(300 \mathrm{mV})$. The peak separation of $49 \mathrm{mV}$ and $71 \mathrm{mV}$ at the 
scan rates of 10 and $100 \mathrm{mV} \mathrm{s}^{-1}$, respectively, are in good agreement with previously published data. $\mathrm{E}_{\mathrm{m}}$ values of $P$. aeruginosa azurin adsorbed on gold electrodes modified with different thiols were estimated to range from 310 to $410 \mathrm{mV} v s$. NHE (Sakurai et al., 1996; Jeuken et al., 2000; Jeuken et al., 2002; Lisdat, Karube 2002; Andolfi et al., 2004; Armstrong et al., 2004). Azurin adsorbed on the bare gold electrode, as well as on the MU-MUAmodified gold electrode, showed far lower and less stable redox peaks (Fig. 2). DTSSP was, thus, chosen as an electrode modifier for the immobilisation of azurin at the surface of gold in the following our study and application of azurin-modified electrodes.

By varying the scan rate and measuring the peak separation in CVs of azurin-modified electrodes the heterogeneous ET rate constant $k_{s}$ was determined to range between 2-6 s ${ }^{-1}$ according to the method of Laviron (Laviron, 1979). Transfer coefficient $\alpha=0.5$ was used in these calculations. This rate constant is very close to the previously reported values of $3-6 \mathrm{~s}^{-1}$ for $P$. aeruginosa azurin immobilized on gold via a mercaptosuccinic acid (MSA) monolayer (Lisdat and Karube, 2002) and it is comparable to $4-12 \mathrm{~s}^{-1}$ determined by Gaigalas and Niaura for azurin adsorbed on a hydrophobic surface of hexane thiol (Gaigalas and Niaura, 1997).

The surface concentration, $\Gamma^{0}$, of the redox-active azurin on DTSSP-modified gold

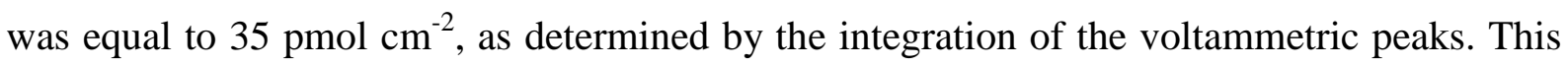
value is 2.3 times higher if compared to the complete monolayer of cyt $c$ usually observed at thiol-modified gold electrodes (15 pmol cm $\mathrm{cm}^{-2}$; Song et al., 1993). Surface concentration of azurin found in our study is in good agreement with previously reported coverage for the monolayer of azurin adsorbed on gold electrodes (32 pmol cm${ }^{-2}$; Andolfi et al., 2004).

\subsection{Detection of $\mathrm{O}_{2}{ }^{--}$and response to interferences}

$\mathrm{O}_{2}{ }^{\bullet-}$ produced by several methods was used to study the reaction between $\mathrm{O}_{2}{ }^{\bullet-}$ and azurin immobilised at DTSSP-modified gold electrode. If the electrode was polarized at +500 $\mathrm{mV}$ vs. NHE, the amperometric detection of $\mathrm{O}_{2}{ }^{--}$was feasible, as shown in Fig. 3. With the 
enzymatic $\mathrm{O}_{2}{ }^{\bullet-}$ generation system, a steady-state current signal from the electrode was obtained within 10-20 s after the injection of the XOD into xanthine solution (Fig. 3). Similar responses have been reported for $\mathrm{O}_{2}{ }^{\bullet-}$ detection by cyt $c$-modified electrodes (Tammeveski et al., 1998; Ge and Lisdat, 2002). When $20 \mu \mathrm{l}$ of the $\mathrm{KO}_{2}$ stock solution in DMSO was injected at $1 \mathrm{~mm}$ distance between the point of $\mathrm{KO}_{2}$ injection and the electrode, a high $4.5 \mathrm{nA}$ current peak output from the azurin electrode was obtained (Fig. 4, curve 1). (In the absence of $\mathrm{O}_{2}{ }^{\bullet-}$ dismutation the addition would generate $10 \mu \mathrm{M}$ of $\mathrm{O}_{2}{ }^{--}$according to Eq. 2). However, when the distance was increased to $10 \mathrm{~mm}$ no pronounced signal from $\mathrm{O}_{2}{ }^{\bullet-}$ was obtained even with significantly higher concentration of $\mathrm{KO}_{2}$. This proves that due to rapid dismutation of $\mathrm{O}_{2}{ }^{\bullet-}$ the detection is only possible if the compound is generated close to the electrode surface.

To keep azurin completely oxidised (i.e., to ensure that the $\mathrm{T} 1$ copper is in $\mathrm{Cu}^{2+}$ state for optimal $\mathrm{O}_{2}{ }^{--}$registration) the applied potential of $+500 \mathrm{mV}$ vs. NHE was chosen as can be justified by looking at CVs of azurin-modified electrodes (Fig. 2). This is, however, a high potential, which might impose electrochemical oxidation of interferences such as uric acid, $\mathrm{H}_{2} \mathrm{O}_{2}$, and DMSO. Both, $\mathrm{H}_{2} \mathrm{O}_{2}$ and uric acid, are the final products in the XOD based $\mathrm{O}_{2}{ }^{\bullet-}$ generation system, and belong to the most serious interfering substances also in in vivo application of electrochemical methods (Lisdat and Karube, 2002). Insignificant interference of both substances has been reported at cyt $c$-modified electrodes when polarized at lower than $+450 \mathrm{mV}$ vs. NHE (Ge and Lisdat, 2002). The optimal potential range in which minimum interference could be guaranteed was found to be in the range $350-400 \mathrm{mV} v s$. NHE, whereas $100 \mathrm{mV}$ higher applied potential was used in our experiments. To clarify the situation with possible interference from uric acid, $\mathrm{H}_{2} \mathrm{O}_{2}$, and DMSO on the current response of the azurin-modified electrodes the control experiments were performed. We would like to emphasize that the optimum applied potential for every particular azurin-modified electrode can be assessed by $\mathrm{CV}$ before the use of the electrode as $\mathrm{O}_{2}{ }^{--}$sensitive biosensor. Usually, such a potential could be lower than $+500 \mathrm{mV}$ vs. NHE. 
As can be seen from Fig. 3A, no interference from uric acid and $\mathrm{H}_{2} \mathrm{O}_{2}$ was observed in $10^{\text {th }} \mu \mathrm{M}$ range. However, a high oxidative current was recorded, when $100^{\text {th }} \mu \mathrm{M}$ concentration of $\mathrm{H}_{2} \mathrm{O}_{2}$ (Fig. 4, curves 2) and uric acid (data not shown) was reached. DMSO, a common solvent for numerous drugs in biomedical investigations, showed much lower response (Fig. 4, curves 3). These results are in good agreement with previously published data describing the behaviour of uric acid and peroxide at the electrodes polarized at the potential higher than $+450 \mathrm{mV}$ (Ge and Lisdat, 2002). It should be emphasized that the influence of the interferences on the signal of the biosensor highly depended on the quality of the modified electrode. In general, the more sensitive was the azurin-modified gold electrode towards $\mathrm{O}_{2}{ }^{\bullet-}$ the lower was the signal from the interfering compound.

\subsection{Kinetic analysis and calibration}

The $\mathrm{O}_{2}^{\bullet-}$ detection system based on cyt $c$ or azurin rely on reaction of $\mathrm{O}_{2}^{\bullet-}$ with immobilized redox proteins (Fig. 1) followed by ET from the reduced adsorbed protein $\left(\mathrm{P}_{\text {red }}^{\mathrm{ads}}\right)$ to the electrode:

$$
\mathrm{P}_{\text {ox }}^{\text {ads }}+\mathrm{O}_{2}^{\bullet-} \rightarrow \mathrm{P}_{\text {red }}^{\text {ads }}+\mathrm{O}_{2}
$$

$$
\begin{gathered}
k_{5} \\
\mathrm{P}_{\text {red }}^{\mathrm{ads}} \rightarrow \mathrm{P}_{\text {ox }}^{\mathrm{ads}}+\mathrm{e}^{-}(\text {electrode })
\end{gathered}
$$

The reaction rate between the adsorbed protein and $\mathrm{O}_{2}{ }^{\bullet-}$ can be described by

$$
v_{4}=k_{4} \Gamma^{0}\left[\mathrm{O}_{2}^{\cdot-}\right]
$$

According to the Butler-Volmer equation

$$
k_{5}=k_{s} \exp \left\{(1-\alpha) n F\left(E-E^{0 \prime}\right) / R T\right\}
$$


where $k_{s} \approx 4 \mathrm{~s}^{-1}$ is a standard rate constant determined from $\mathrm{CV}$ s of the azurin-modified gold electrodes (see Section 3.1), $E$ is applied potential $(0.50 \mathrm{~V} v s . \mathrm{NHE}), E^{0 \prime}$ is formal potential (0.38 V vs. NHE), and $\alpha, F, R$, and $T$ have their usual meaning.

Comprehensive kinetic analysis of the biosensor based on cyt $c$-modified electrode was presented previously (Tammeveski et al., 1998; Ge and Lisdat, 2002), as well as the calibration of the sensor using enzymatic and chemical $\mathrm{O}_{2}{ }^{\bullet-}$ generations has been evaluated (Ge and Lisdat, 2002). It was shown that at $\left[\mathrm{O}_{2}{ }^{-}\right]<<\left(\frac{k_{5}}{k_{4}}\right)$, i.e., when the sensor is not controlled by the rate of heterogeneous ET, the sensor signal will be directly proportional to the $\mathrm{O}_{2}{ }^{\bullet-}$ concentration:

$$
\frac{i}{A}=n F k_{4} \Gamma^{0}\left[\mathrm{O}_{2}^{\cdot-}\right]=k_{r}\left[\mathrm{O}_{2}^{\cdot-}\right]
$$

where: $i$ is sensor signal (current output from the electrode) and $A$ is electrode area. It is obvious that the sensor sensitivity, $k_{r}$, will increase at higher $k_{4}$ and $\Gamma^{0}$. However, $k_{r}$ from the equation $k_{r}=n F k_{4} \Gamma^{0}$ could not be calculated precisely as the rate constant $k_{4}$ of the reaction between covalently immobilized azurin and $\mathrm{O}_{2}{ }^{--}$is unknown. Previously, the rate constant for cyt $c$ reaction with $\mathrm{O}_{2}{ }^{\bullet-}$ at homogeneous (solution), $k_{4}^{\prime}$, (Eq. 8) and heterogeneous, $k_{4}$, (Eq. 4) conditions (for cyt $c$ immobilized on a mixed-thiol-modified gold electrodes) were determined to be equal to $2.6 \cdot 10^{5} \mathrm{M}^{-1} \mathrm{~s}^{-1}$ and $0.3 \cdot 10^{5} \mathrm{M}^{-1} \mathrm{~s}^{-1}$, respectively (Butler et al., 1982; Ge and Lisdat, 2002).

$$
\mathrm{P}_{\text {ox }}^{\mathrm{aq}}+\mathrm{O}_{2}^{\bullet-} \stackrel{k_{4}^{\prime}}{\rightarrow} \mathrm{P}_{\text {red }}^{\mathrm{aq}}+\mathrm{O}_{2}
$$

where $\mathrm{P}^{\mathrm{aq}}$ is protein (cyt $c$ or azurin) in solution. 
In order to estimate homogeneous rate constant, $k^{\prime}{ }_{4}$, for the reaction of the azurin with $\mathrm{O}_{2}{ }^{\bullet-}$, a reduction of cyt $c$ and azurin by $\mathrm{O}_{2}^{\bullet-}$ was spectrophotometrically measured and compared (see data in Fig. 5). Both proteins could be easy reduced by $\mathrm{O}_{2}{ }^{\bullet-}$ produced during the enzymatic reaction of XOD with xanthine (Fig. 5A). The reduction rate of cyt $c$ was measured by the increase of the absorption at $550 \mathrm{~nm}$. For azurin the disappearance of the blue colour $\left(\lambda_{\max } 628 \mathrm{~nm}\right)$ corresponds to its reduction in the solution. Since the extinction coefficients are known (cyt $c-23.9 \mathrm{mM}^{-1} \mathrm{~cm}^{-1}$ (Sober, 1969) and azurin $-5.7 \mathrm{mM}^{-1} \mathrm{~cm}^{-1}$ (Goldberg and Pecht, 1976)), the kinetic estimates of the reduction processes could be done for both proteins. As can be seen from Fig. 5B the reduction rate of cyt $c$ is higher compared to azurin, and after short time a fully reduced protein could be obtained in the solution containing a high concentration of XOD, whereas longer exposure of azurin to $\mathrm{O}_{2}{ }^{--}$is needed in order to get fully reduced azurin (Fig. 5B, doted curve 1). From the kinetic curves, the rate constant $k^{\prime}{ }_{4}$ of the homogeneous reaction azurin $-\mathrm{O}_{2}{ }^{\bullet-}$ has been approximated to be of about $10^{5} \mathrm{M}^{-1} \mathrm{~s}^{-1}$ taken into account the value previously determined for cyt $c\left(2.6 \cdot 10^{5} \mathrm{M}^{-1} \mathrm{~s}^{-1} 1\right.$; Butler et al., 1982). In this approximation the following values were used: concentration of both proteins was equal to $0.1 \mathrm{mg} / \mathrm{ml}$, the initial rates of the reactions for cyt $c$ and azurin reduction were found to be 0.76 and 0.24 nmole s $^{-1}$ at $250 \mathrm{mU} / \mathrm{ml}$ of XOD, and 0.08 and 0.05 nmole $\mathrm{s}^{-1}$ at $25 \mathrm{mU} / \mathrm{ml}$ of XOD, respectively. Taking into account the value $k_{4}^{\prime}=10^{5} \mathrm{M}^{-1} \mathrm{~s}^{-1}$, the maximum sensitivity, $k_{r}$, of the azurin-modified electrodes could be approximated to 3.4 $10^{3} \mathrm{~A} \mathrm{~m}^{-2} \mathrm{M}^{-1}$ if assuming $k_{4}^{\prime}=k_{4}$. The most probable is that this equality does not hold and that $k_{4}^{\prime}>k_{4}$. It is well known that the reactions driven by enzymes in heterogeneous conditions are slower than in homogeneous solutions. The $k_{4}$ will, thus, be calculated below from the experimentally determined sensitivity of the electrodes. 
When a superoxide sensitive biosensor responds to $\mathrm{O}_{2}{ }^{\bullet-}$ from the XOD reaction, a steady-state sensor signal is obtained due to equilibration of two opposite processes. $\mathrm{O}_{2}{ }^{\bullet-}$ dismutation (Eq. 1) and its generation (Eq. 2) at steady-state leads that $k_{1}\left[O_{2}^{\bullet-}\right]^{2}=k_{c a t} E_{X O D}$, where $k_{c a t}$ and $E_{X O D}$ are catalytic rate constant and the concentration of the enzyme (XOD) in the solution. This means that the steady-state current response of the biosensor to $\mathrm{XOD}$ generated $\mathrm{O}_{2}{ }^{\bullet-}$ will be proportional to the square root of XOD activity (McCord and Fridovich, 1968). From Fig. 3B it is seen that such dependence holds up to $100 \mathrm{mU}$ of XOD per ml. This fact suggests also that the sensor signal is not limited by $k_{5}$. The $k_{1}$ and $k_{c a t}$ values were previously determined to be equal to $2.3 \cdot 10^{5} \mathrm{M}^{-1}$ $\mathrm{s}^{-1}$ and $1 \mathrm{~s}^{-1}$, respectively under the air-saturated conditions at $\mathrm{pH} 7.5$ (Ge and Lisdat, 2002). Taking into account the values of these constants, specific XOD activity of $1.3 \mathrm{U} \mathrm{mg}^{-1}$ and the molecular weight of the enzyme equal to $300 \mathrm{kDa}$ (Nagler and Vartanyan, 1976; Eger et al., 2000) it is possible to calculate the sensitivity of the azurin-based sensor as being equal to $6.8 \cdot 10^{2} \mathrm{~A} \mathrm{~m}^{-2} \mathrm{M}^{-1}$. In more simple terms this calculation could be simplified if accepting the estimate that $1 \mu \mathrm{M}$ steady-state concentration of $\mathrm{O}_{2}{ }^{--}$is present in the solution containing 50 mU per mL XOD activity (Tammeveski et al., 1998; Ge and Lisdat, 2002). The $k_{r}$ value of $6.8 \cdot 10^{2} \mathrm{~A} \mathrm{~m}^{-2} \mathrm{M}^{-1}$ is about 12 times higher if compared to the sensitivity of the cyt $c$ electrode immobilised on the same thiol layer $\left(0.5610^{2} \mathrm{~A} \mathrm{~m}^{-2} \mathrm{M}^{-1}\right.$; Tammeveski et al., 1998), approximately 2.5 times higher if compared to the sensitivity of cyt $c$ immobilized on the mixed long length thiols $\left(2.7610^{2} \mathrm{~A} \mathrm{~m}^{-2} \mathrm{M}^{-1}\right.$; Ge and Lisdat, 2002), and it is twice lower if compared to the sensitivity of the multilayer cyt $c$ electrodes $\left(13.8 \cdot 10^{2} \mathrm{~A} \mathrm{~m}^{-2} \mathrm{M}^{-1}\right.$; Beissenhirtz et al., 2004).

Taking the $k_{r}$ value from the experiments $\left(6.8 \cdot 10^{2} \mathrm{~A} \mathrm{~m}^{-2} \mathrm{M}^{-1}\right)$, the rate constant $k_{4}$ can be calculated to be equal to $0.2 \cdot 10^{5} \mathrm{M}^{-1} \mathrm{~s}^{-1}$. The constant is 5 times lower than $k_{4}^{\prime}$, i.e., the 
immobilisation of the azurin by DTSSP on gold reduces reactivity of the T1 site with $\mathrm{O}_{2}{ }^{\bullet-}$. To our best knowledge there is no calculated data about $k_{4}$ and $\Gamma^{0}$ values for cyt $c$ absorbed on the identical thiol layer (DTSSP). However, our values can be compared with similar data calculated for cyt $c$ immobilised on the on the mixed long length thiols (Ge and Lisdat, 2002). $k_{4}$ value for the immobilised azurin was about 1.5 times lower than the same constant for monolayer of cyt $c$ immobilised on the mercaptoundecanoic acid/mercaptoundecanol modified gold electrodes (Ge and Lisdat, 2002). Taking into account the $k_{4}$ values of azurin on DTSSP layer and cyt $c$ immobilised on the mixed long length thiols $\left(0.2 \cdot 10^{5} \mathrm{M}^{-1} \mathrm{~s}^{-1}\right.$ and $0.3 \cdot 10^{5} \mathrm{M}^{-1} \mathrm{~s}^{-1}$, respectively) and keeping in mind that surface concentration of azurin was 3.8 times higher than that for monolayer of cyt $c$ immobilised on the mixed long length thiols (35

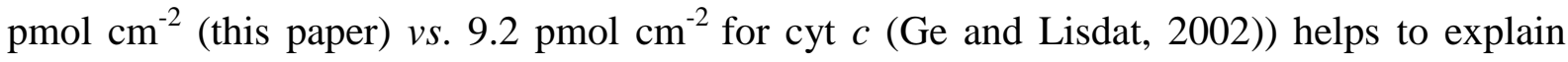
superior sensitivity of the azurin-based biosensor $\left(6.8 \cdot 10^{2} \mathrm{~A} \mathrm{~m}^{-2} \mathrm{M}^{-1}\right)$ vs. cyt $c$ monolayer electrodes $\left(2.7610^{2} \mathrm{~A} \mathrm{~m}^{-2} \mathrm{M}^{-1}\right)$, since the sensitivity is directly proportional to $k_{4} \times \Gamma^{0}$.

\subsection{Monitoring of $\mathrm{O}_{2}{ }^{\bullet-}$ production from neutrophils}

The azurin-based biosensor and well-known luminol-amplified chemiluminescence assay for monitoring of reactive oxygen species (ROS) were used to measure $\mathrm{O}_{2}{ }^{\bullet-}$ production from human neutrophils. A typical current response as well as chemiluminescence signal recorded with the azurin-modified electrode and Biolumat are shown in Fig. $6 \mathrm{~A}$ and B, respectively. The responses were generated by $10^{6}-2 \cdot 10^{7}$ neutrophil concentration per ml, which was achieved by addition of the concentrated cell solution from freshly collected venous blood in to the measurement cuvettes hosting either azurin-modified electrode or the solution of Biolumat. The immediate responses to addition of the neutrophils shown by the two methods can be explained by the production of ROS from the stressed neutrophils during their transfer to the warm solution $\left(37^{\circ} \mathrm{C}\right)$ after storage on melting ice. With the azurin 
electrode (Fig. 6A) the current obtained corresponds to the extracellular $\mathrm{O}_{2}{ }^{\bullet-}$ concentration of about $2 \mu \mathrm{M}$. During following $300 \mathrm{sec}$ the cells in measurement cuvettes warm up and the signals from both measurement methods stabilise (Fig. 6). After that, the stimulators (only response to fLMF is shown in Fig. 6) were added into the solution resulting into a well pronounced luminol-amplified chemiluminescence signal. The response is approximately 1000 times higher if compared to signal without stimuli (Fig. 6B). This result is in a good agreement with previously published data (Mills et al., 1980; Dahlgren et al., 1985; Panasenko et al., 1991; Samuni et al., 1991). The stimulator, however, increased the current response of the azurin-modified electrode only moderately (Fig. 6A). One of the simplest explanations for the different output from the electrochemical and the photometric measurements can be the following. The luminol-amplified chemiluminescence method detects both intra- and extracellular production of several types of ROS, whereas the electrochemical signal corresponds specifically to the extracellular $\mathrm{O}_{2}{ }^{--}$released from neutrophils in close proximity of the electrode. The current from the $\mathrm{O}_{2}{ }^{\bullet-}$ sensitive biosensor as well as the luminol-amplified chemiluminescence signal depended quantitatively on the concentration of cells as well as the type of stimuli. The addition of SOD resulted in a sharp decrease in both electrochemical and optical signals (Fig. 6). The results obtained by combined optical and electrochemical measurements of ROS from neutrophils require future clarification. Biosensors for $\mathrm{O}_{2}{ }^{\bullet-}$ detection will be helpful in understanding radical reactions at cellular level.

\section{Conclusions}

The azurin-DTSSP-modified electrode is a highly sensitive amperometric $\mathrm{O}_{2}{ }^{\bullet-}$ biosensor. The signals from interfering $\mathrm{H}_{2} \mathrm{O}_{2}$, uric acid, and DMSO are negligible at the concentration below $10 \mu \mathrm{M}$. The rate constant of the reaction between azurin and $\mathrm{O}_{2}{ }^{--}$in solution is approximately $10^{5} \mathrm{M}^{-1} \mathrm{~s}^{-1}$, and the rate constant of the reaction between the 
DTSSP-immobilised azurin and $\mathrm{O}_{2}^{\bullet-}$ is approximately $0.2 \cdot 10^{5} \mathrm{M}^{-1} \mathrm{~s}^{-1}$. Based on electrochemical data the sensitivity of the azurin-biosensor towards $\mathrm{O}_{2}{ }^{\bullet-}$ was calculated to be equal to $6.8 \cdot 10^{2} \mathrm{~A} \mathrm{~m}^{-2} \mathrm{M}^{-1}$. The biosensor is also applicable in a detection of extracellular $\mathrm{O}_{2}{ }^{\bullet-}$ from human neutrophils.

\section{Acknowledgements}

Financial support from the European Community (contract QLK3-CT-2001-00244), the Swedish Society for Medicine, and the Swedish Research Council is acknowledged. 


\section{References}

Amatore, C., Arbault, S., Bruce, D., de Oliveira, P., Erard, M., Vuillaume, M., 2000. Analysis of individual biochemical events based on artificial synapses using ultramicroelectrodes: cellular oxidative burst. Faraday Discuss. 116, 319-333.

Andolfi, L., Bruce, D., Cannistraro, S., Canters, G.W., Davis, J.J., Hill, H.A.O., Crozier, J., Verbeet, M.P., Wrathmell, C.L., Astier, Y., 2004. The electrochemical characteristics of blue copper protein monolayers on gold. J. Electroanal. Chem. 565, 21-28.

Armstrong, F.A., Barlow, N.L., Burn, P.L., Hoke, K.R., Jeuken, L.J.C., Shenton, C., Webster, G.R., 2004. Fast, long-range electron-transfer reactions of a "blue" copper protein coupled non-covalently to an electrode through a stilbenyl thiolate monolayer. Chem. Commun. 3, 316-317.

Armstrong, F.A., Bond, A.M., Hill, H.A.O., Oliver, B.N., Psalti, I.S.M., 1989. Electrochemistry of cytochrome $c$, plastocyanin, and ferredoxin at edge- and basal-plane graphite electrodes interpreted via a model based on electron transfer at electroactive sites of microscopic dimensions in size. J. Am. Chem. Soc. 111, 9185-9189.

Armstrong, F.A., Hill, H.A.O., Oliver, B.N., Walton, N.J., 1984. Direct electrochemistry of redox proteins at pyrolytic graphite electrodes. J. Am. Chem. Soc. 106, 921-923.

Armstrong, F.A., Hill, H.A.O., Oliver, B.N., Whitford, D., 1985. Direct electrochemistry of the photosynthetic blue copper protein plastocyanin. Electrostatic promotion of rapid charge transfer at an edge-oriented pyrolytic graphite electrode. J. Am. Chem. Soc. 107, 1473-1476. Barbacanne, M.A., Souchard, J.P., Darblade, B., Iliou, J.P., Nepveu, F., Pipy, B., Bayard, F., Arnal, J.F., 2000. Detection of superoxide anion released extracellularly by endothelial cells using cytochrome $c$ reduction, ESR, fluorescence and lucigenin-enhanced chemiluminescence techniques. Free Radical Bio. Med. 29, 388-396.

Beissenhirtz, M.K., Scheller, F.W., Lisdat, F., 2004. A superoxide sensor based on a multilayer cytochrome $c$ electrode. Anal. Chem. 76, 4665-4671. 
Berezin, I.V., Bogdanovskaya, V.A., Varfolomeev, S.D., Tarasevich, M.R., Yaropolov, A.I., 1978. Bioelectrocatalysis. Equilibrium oxygen potential in the presence of laccase. Dokl. Akad. Nauk SSSR 240, 615-618.

Brill, A.S., Bryce, G.F., Maria, H.J., 1968. Optical and magnetic properties of Pseudomonas azurins. Biochim. Biophys. Acta 154, 342-351.

Buechi, F.N., Bond, A.M., Codd, R., Huq, L.N., Freeman, H.C., 1992. Electrochemical investigations of poplar, spinach, cucumber, and parsley plastocyanins at conventional and microsized carbon electrodes. Inorg. Chem. 31, 5007-5014.

Butler, J., Koppenol, W.H., Margoliash, E., 1982. Kinetics and mechanism of the reduction of ferricytochrome $c$ by the superoxide anion. J. Biol. Chem. 257, 10747-10750.

Böyum, A. 1968. Isolation of mononuclear cells and granulocytes from human blood. Isolation of monuclear cells by one centrifugation, and of granulocytes by combining centrifugation and sedimentation at 1 g. Scand. J. Clin. Lab. Invest. Suppl. 97, 77-89.

Campanella, L., Favero, G., Tomassetti, M., 1997. A modified amperometric electrode for the determination of free radicals. Sensor. Actuat. B-Chem. B44, 559-565.

Cooper, J.M., Thompson, G., McNeil, C.J., 1993. Direct electron transfer between immobilized cytochrome $c$ and gold electrodes. Mol. Cryst. Liq. Crys. A 235, 127-132.

Dahlgren, C., Aniansson, H., Magnusson, K.E., 1985. Pattern of formylmethionyl-leucylphenylalanine-induced luminol- and lucigenin-dependent chemiluminescence in human neutrophils. Infection Immun. 47, 326-328.

Eger, B.T., Okamoto, K., Enroth, C., Sato, M., Nishino, T., Pai, E.F., 2000. Purification, crystallization and preliminary X-ray diffraction studies of xanthine dehydrogenase and xanthine oxidase isolated from bovine milk. Acta Crystallogr., Sect D: Biol. Crystallogr. 56, $1656-1658$. 
Ferrante, A., Thong, Y. H., 1980. Optimal conditions for simultaneous purification of mononuclear and polymorphonuclear leucocytes from human blood by the Hypaque-Ficoll method. J. Immunol. Methods 36, 109-117.

Finkel, T., 1999. Signal transduction by reactive oxygen species in non-phagocytic cells. J. Leukocyte Biol. 65, 337-340.

Finkel, T., Holbrook, N.J., 2000. Oxidants, oxidative stress and the biology of ageing. Nature 408, 239-247.

Ge, B., Lisdat, F., 2002. Superoxide sensor based on cytochrome $c$ immobilized on mixedthiol SAM with a new calibration method. Anal. Chim. Acta 454, 53-64.

Gaigalas, A.K., Niaura, G., 1997. Measurement of electron transfer rates between adsorbed azurin and a gold electrode modified with a hexanethiol layer. J. Colloid and Interf. Sci. 193, $60-70$.

Goldberg, M., Pecht, I., 1976. Kinetics and equilibriums of the electron transfer between azurin and the hexacyanoiron (II/III) couple. Biochemistry 15, 4197-4208.

Gray, H.B., Malmstrom, B.G., Williams, R.J.P., 2000. Copper coordination in blue proteins. J. Biol. Inorg. Chem. 5, 551-559.

Jeuken, L.J.C., McEvoy, J.P., Armstrong, F.A., 2002. Insights into gated electron-transfer kinetics at the electrode-protein interface: a square wave voltammetry study of the blue copper protein azurin. J. Phys. Chem. B 106, 2304-2313.

Jeuken, L.J.C., van Vliet, P., Verbeet, M.P., Camba, R., McEvoy, J.P., Armstrong, F.A., Canters, G.W., 2000. Role of the surface-exposed and copper-coordinating histidine in blue copper proteins: the electron-transfer and redox-coupled ligand binding properties of His117Gly azurin. J. Am. Chem. Soc. 122, 12186-12194.

Kaim, W., Rall, J., 1996. Copper - A "modern" bioelement. Angew. Chem. Int. Ed. Engl. 35, 43-60. 
Kang, Y.J., 1999. The antioxidant function of metallothionein in the heart. Proc. Soc. Exp. Biol. Med. 222, 263-273.

Kondoh, M., Inoue, Y., Atagi, S., Futakawa, N., Higashimoto, M., Sato, M., 2001. Specific induction of metallothionein synthesis by mitochondrial oxidative stress. Life Sci. 69, 2137 2146.

Kumari, M.V.R., Hiramatsu, M., Ebadi, M., 2000. Free radical scavenging actions of hippocampal metallothionein isoforms and of antimetallothioneins: an electron spin resonance spectroscopic study. Cell. Mol. Biol. 46, 627-636.

Kuznetsov, B.A., Byzova, N.A., Shumakovich, G.P., Mazhorova, L.E., Mutuskin, A.A., 1996. Electrochemical investigation of binding sites of plantacyanin: blue, copper-containing protein of plants. Bioelectrochemistry 40, 249-255.

Lander, H.M., 1997. An essential role for free radicals and derived species in signal transduction. FASEB J. 11, 118-124.

Laviron, E., 1979. General expression of the linear potential sweep voltammogram in the case of diffusionless electrochemical systems. J. Electroanal. Chem. 101, 19-28.

Li, H., Webb, S.P., Ivanic, J., Jensen, J.H., 2004. Determinants of the relative reduction potentials of type-1 copper sites in proteins. J. Am. Chem. Soc. 126, 8010-8019.

Lisdat, F., Ge, B., Ehrentreich-Foerster, E., Reszka, R., Scheller, F.W., 1999. Superoxide dismutase activity measurement using cytochrome $c$-modified electrode. Anal. Chem. 71, $1359-1365$.

Lisdat, F., Karube, I., 2002. Copper proteins immobilised on gold electrodes for (bio)analytical studies. Biosens. Bioelectron. 17, 1051-1057.

Manning, P., McNeil, C.J., Cooper, J.M., Hillhouse, E.W., 1998. Direct, real-time sensing of free radical production by activated human glioblastoma cells. Free Radical Biol. Med. 24, 1304-1309. 
McCord, J.M., Fridovich, I., 1968. The reduction of cytochrome $c$ by milk xanthine oxidase. J. Biol Chem. 243, 5753-5760.

McNeil, C.J., Athey, D., Ho, W.O., 1995. Direct electron transfer bioelectronic interfaces: application to clinical analysis. Biosens. Bioelectron. 10, 75-83.

McNeil, C.J., Manning, P., 2002. Sensor-based measurements of the role and interactions of free radicals in cellular systems. Rev. Mol. Biotechnol. 82, 443-455.

Messerschmidt, A., Huber, R., Poulos, T., Wieghardt, K., 2001. Handbook of metalloproteins. $1-2,1472$.

Mills, E.L., Rholl, K.S., Quie, P.G., 1980. Luminol-amplified chemiluminescence: a sensitive method for detecting the carrier state in chronic granulomatous disease. J. Clin. Microbiol. 12, $52-56$.

Nagler, L.G., Vartanyan, L.S., 1976. Subunit structure of bovine milk xanthine oxidase. Effect of limited cleavage by proteolytic enzymes on activity and structure. Biochim. Biophys. Acta 427, 78-90.

Nar, H., Messerschmidt, A., Huber, R., Van de Kamp, M., Canters, G.W., 1991. Crystal structure analysis of oxidized Pseudomonas aeruginosa azurin at $\mathrm{pH} 5.5$ and $\mathrm{pH}$ 9.0. A pHinduced conformational transition involves a peptide bond flip. J. Mol. Biol. 221, 765-772.

Panasenko, O.M., Vol'nova, T.V., Osipov, A.N., Azizova, O.A., Vladimirov, Y.A., 1991. Free-radical generation by monocytes and neutrophils: a possible cause of plasma lipoprotein modification. Biomedical Sci. 2, 581-589.

Pinho, D., Besson, S., Brondino, C.D., Pereira, E., de Castro, B., Moura, I., 2004. Two azurins with unusual redox and spectroscopic properties isolated from the Pseudomonas chlororaphis strains DSM 50083T and DSM 50135. J. Inorg. Biochem. 98, 276-286.

Reinhammar, B.R.M., 1972. Oxidation-reduction potentials of the electron acceptors in laccases and stellacyanin. Biochim. Biophys. Acta 275, 245-259. 
Sakurai, T., Nose, F., Fujiki, T., Suzuki, S., 1996. Reduction and oxidation processes of blue copper proteins, azurin, pseudoazurin, umecyanin, stellacyanin, plantacyanin, and plastocyanin approached by cyclic and potential step voltammetries. Bull. Chem. Soc. Japan 69, 2855-2862.

Samuni, A., Krishna, C.M., Cook, J., Black, C.D.V., Russo, A., 1991. On radical production by PMA-stimulated neutrophils as monitored by luminol-amplified chemiluminescence. Free Radical Biol. Med. 10, 305-313.

Scheller, W., Jin, W., Ehrentreich-Forster, E., Ge, B., Lisdat, F., Buttemeier, R., Wollenberger, U., Scheller, F.W., 1999. Cytochrome $c$-based superoxide sensor for in vivo application. Electroanalysis 11, 703-706.

Shishido, N., Nakayama, K., Takazawa, A., Ohyama, T., Nakamura, M., 2001. Cumetallothioneins $(\mathrm{Cu}(\mathrm{I}) 8-\mathrm{MTs})$ in LEC rat livers 13 weeks after birth still act as antioxidants. Arch. Biochem. Biophys. 387, 216-222.

Shleev, S., Tkac, J., Christenson, A., Ruzgas, T., Yaropolov, A., Whittaker, J.W., Gorton, L., 2005. Direct electron transfer between copper containing proteins and electrodes. Biosens. Bioelectron. 20, 2517-2554.

Sober, H.S., 1969. Handbook of Bioelectrochemistry. CRC Press (Boca Ration, FL.).

Soininen, R., Ellfolk, N., 1972. Pseudomonas cytochrome $c$ peroxidase. IV. Some kinetic properties of the peroxidation reaction, and enzymatic determination of the extinction coefficients of Pseudomonas cytochrome c-551 and azurin. Acta Chem. Scand. 26, 861-872. Solomon, E.I., Baldwin, M.J., Lowery, M.D., 1992. Electronic structures of active sites in copper proteins: contributions to reactivity. Chem. Rev. 92, 521-542.

Stief, T.W., 2000. The blood fibrinolysis/deep-sea analogy. A hypothesis on the cell signals singlet oxygen/photons as natural antithrombotics. Thromb. Res. 99, 1-20. 
Tammeveski, K., Tenno, T.T., Mashirin, A.A., Hillhouse, E.W., Manning, P., McNeil, C.J., 1998. Superoxide electrode based on covalently immobilized cytochrome $c$ : modeling studies. Free Radical Biol. Med. 25, 973-978.

Van de Kamp, M., Hali, F.C., Rosato, N., Agro, A.F., Canters, G.W., 1990. Purification and characterization of a non-reconstitutable azurin, obtained by heterologous expression of the Pseudomonas aeruginosa azurin gene in Escherichia coli. Biochim. Biophys. Acta 1019, 283 292.

Van Pouderoyen, G., Cigna, G., Rolli, G., Cutruzzola, F., Malatesta, F., Silvestrini, M.C., Brunori, M., Canters, G.W., 1997. Electron-transfer properties of Pseudomonas aeruginosa [Lys44, Glu64] azurin. Eur. J. Biochem. 247, 322-331.

White, C.R., Brock, T.A., Chang, L.Y., Crapo, J., Briscoe, P., Ku, D., Bradley, W.A., Gianturco, S.H., Gore, J., et al., 1994. Superoxide and peroxynitrite in atherosclerosis. P. Natl. Acad. Sci. USA 91, 1044-1048.

Yao, D., Vlessidis, A.G., Evmiridis, N.P., Zhou, Y., Xu, S., Zhou, H., 2002. Novel chemiluminescence method for detection of superoxide anions and its application to dry-cured meat. Anal. Chim. Acta 467, 145-153.

Zhang, J., Chi, Q., Kuznetsov, A.M., Hansen, A.G., Wackerbarth, H., Christensen, H.E.M., Andersen, J.E.T., Ulstrup, J., 2002. Electronic properties of functional biomolecules at metal/aqueous solution interfaces. J. Phys. Chem. B 106, 1131-1152. 


\section{Legends to figures}

Figure 1. Biosensors based on the redox protein. Detection scheme of superoxide radicals.

Figure 2. Voltamograms of Pseudomonas aeruginosa azurin on the bare gold electrode as well as DTSSP-, and MU+MUA-modified gold electrodes (PBS).

(A) $\mathrm{CVs}$ at $10 \mathrm{mV} / \mathrm{sec}$ scan rate, (B) $\mathrm{CVs}$ at $100 \mathrm{mV} / \mathrm{sec}$ scan rate.

Figure 3. Representative current $v s$. time curves for the $\mathrm{O}_{2}{ }^{\bullet-}$ azurin-DTSSP-modified gold electrodes (PBB $+2 \mathrm{mM}$ xanthine). $\mathrm{O}_{2}^{\bullet-}$ was produced by XOD reaction. (A) 1- addition of XOD, 2 - addition of $\mathrm{H}_{2} \mathrm{O}_{2}, 3$ - addition of uric acid (2 and 3 - control experiments). (B) Dependence of the electrode current on XOD concentration. Insert: dependence of the experimental sensor signal on square root of XOD activity.

Figure 4. Representative current $v s$. time curves for the $\mathrm{O}_{2}{ }^{\bullet-}$ azurin-DTSSP-modified gold electrodes (PBS). $\mathrm{O}_{2}{ }^{--}$was produced by $\mathrm{KO}_{2}$ addition to the solution; 1 - addition of $\mathrm{KO}_{2}, 2$ addition of $\mathrm{H}_{2} \mathrm{O}_{2}, 3$ - addition of DMSO (2 and 3 - control experiments).

Figure 5. Monitoring of the reduction of cyt $c$ and azurin by $\mathrm{O}_{2}{ }^{\bullet-}$ generated in the solution by XOD reaction (PBB, 2mM xanthine). (A) Spectral changes: 1 and 2 - oxidized and reduced cyt $c\left(1.2 \cdot 10^{-5} \mathrm{M}\right)$, respectively; 3,4 , and 5 - oxidized, partly reduced, and fully reduced azurin $\left(7.2 \cdot 10^{-5} \mathrm{M}\right)$, respectively. (B) Kinetic curves of the proteins reduction. Solid line - cyt $c\left(8.0 \cdot 10^{-6} \mathrm{M}\right)$, dotted line - azurin $\left(7.2 \cdot 10^{-6} \mathrm{M}\right) .1-250 \mathrm{mU} / \mathrm{ml} \mathrm{XOD}, 2-25 \mathrm{mU} / \mathrm{ml} \mathrm{XOD}$.

Figure 6. Representative detection of neutrophil ROIs following stimulation with $0.1 \mu \mathrm{M}$ fMLF. (A) Amperometric detection of extracellular $\mathrm{O}_{2}{ }^{\bullet-}$ using the azurin-DTSSP-modified gold electrode mounted in the Biolumat. (B) Luminol-amplified chemiluminescence signal in the presence of $4 \mathrm{U} / \mathrm{ml} \mathrm{HRP} .\left(10^{6}\right.$ cells per $\mathrm{ml}, 37^{\circ} \mathrm{C}$, KRG buffer. $\mathrm{Cpm}=$ counts per minute. $)$. 
Figure 1
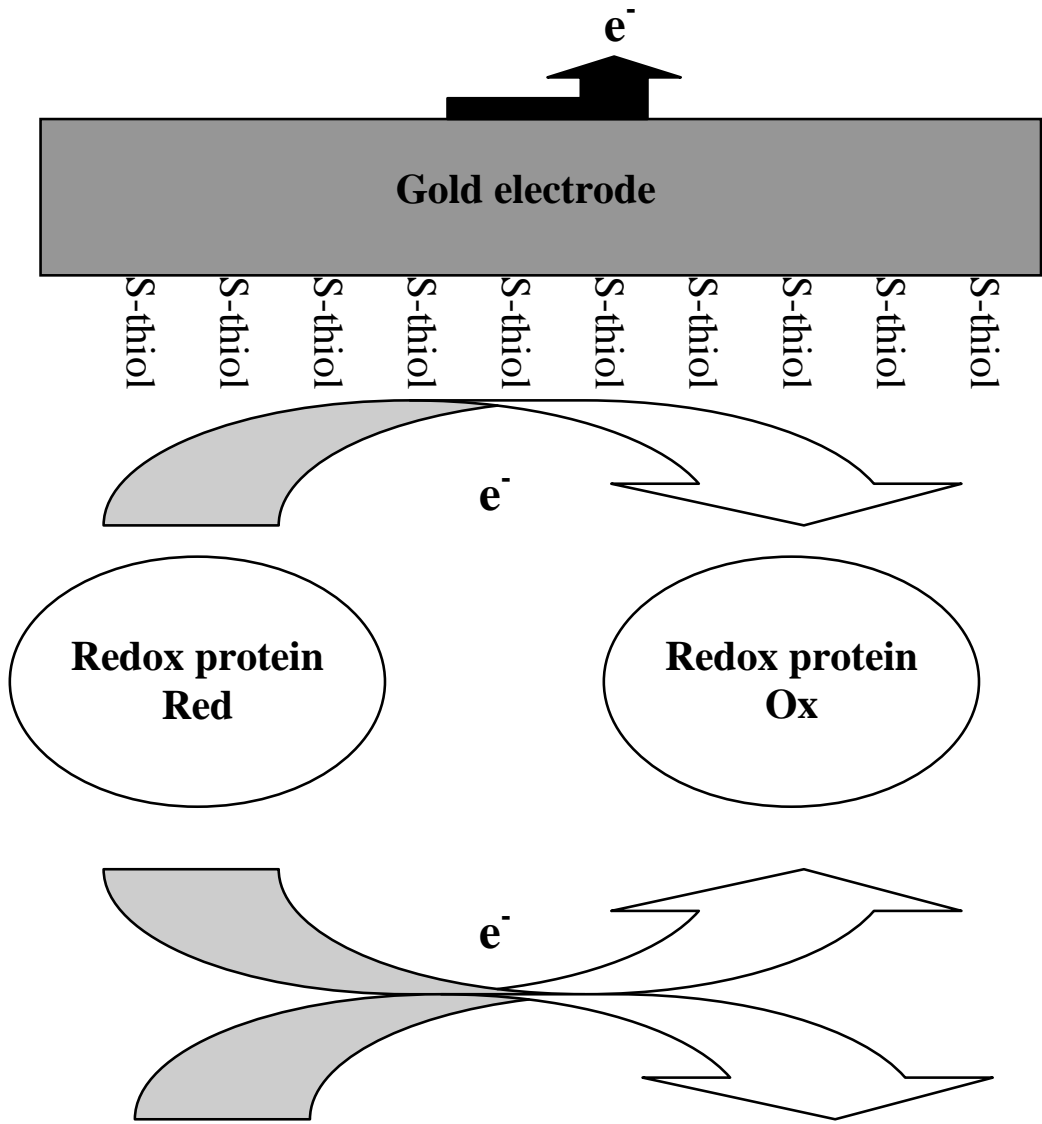

$\mathrm{O}_{2}{ }^{\circ-}$

$\mathrm{O}_{2}$ 
Figure 2

A

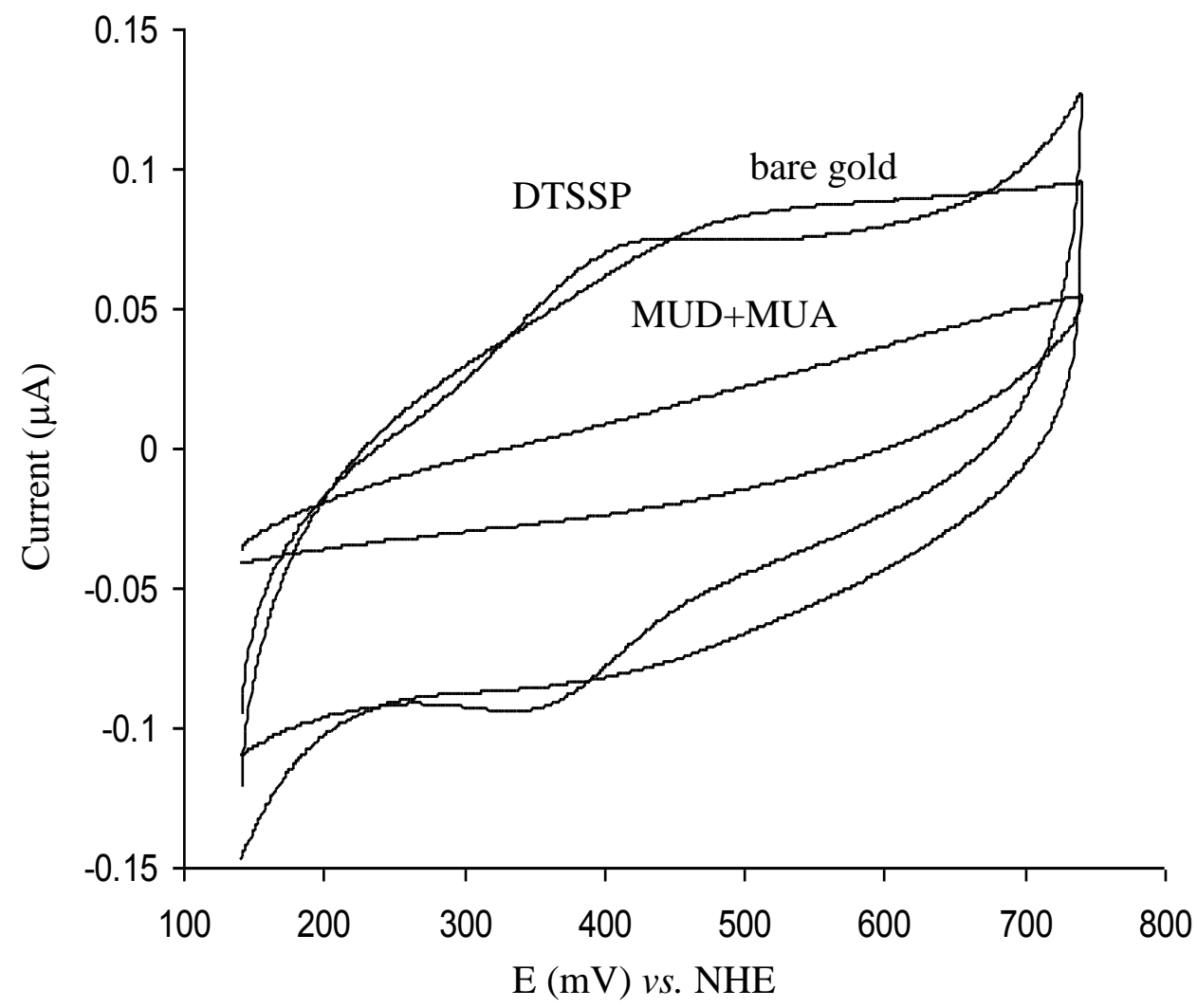

B

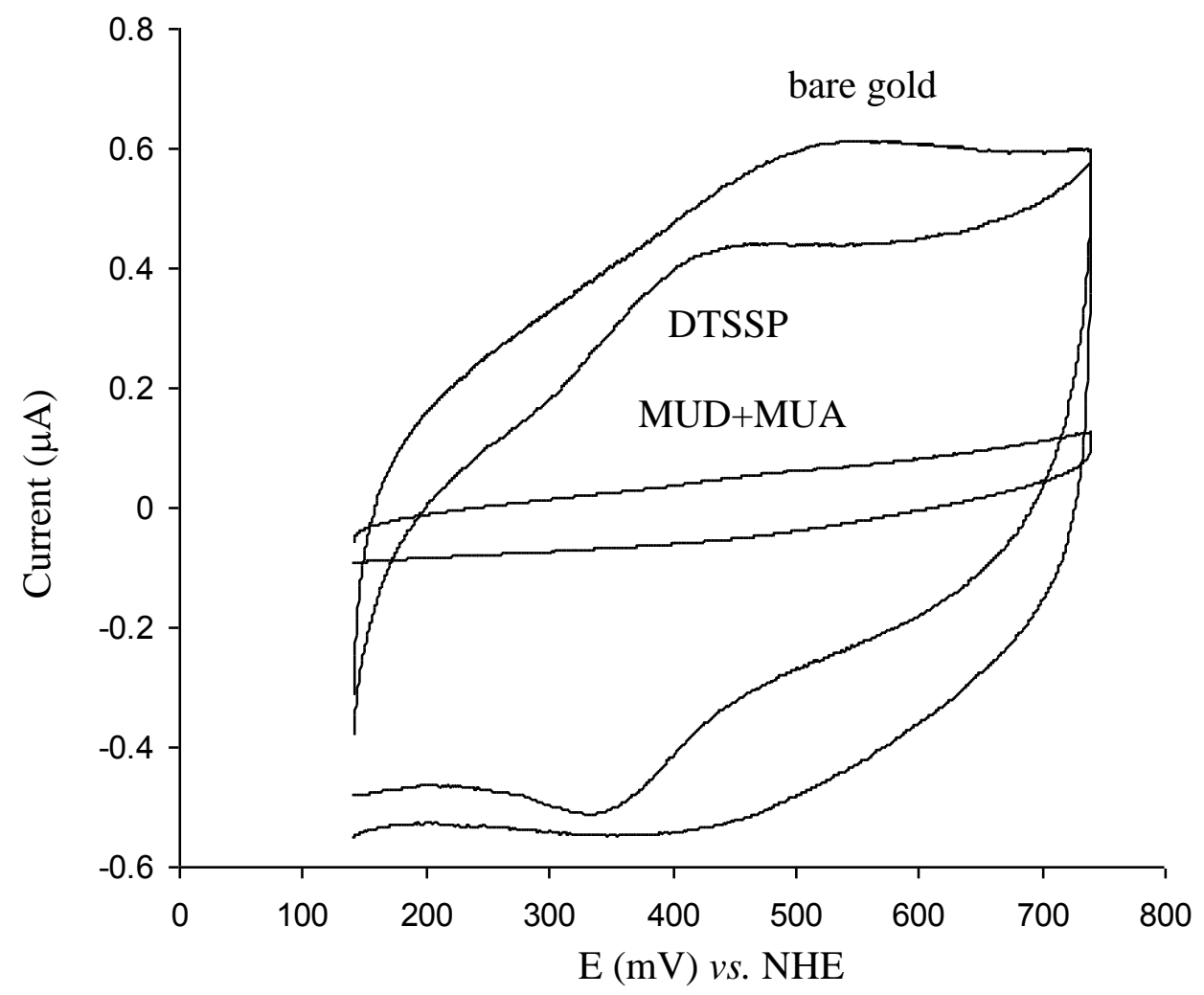


Figure 3

A
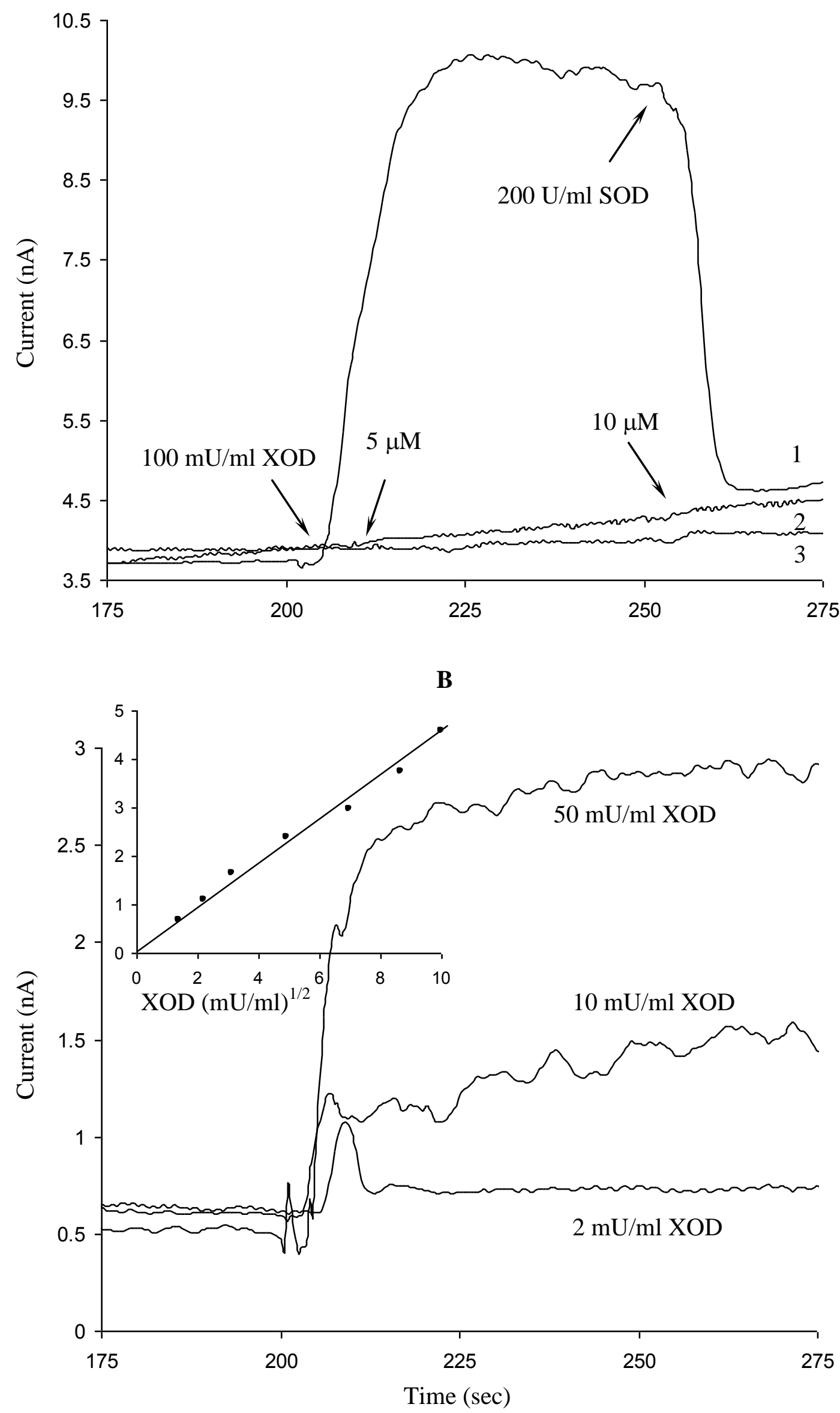
Figure 4

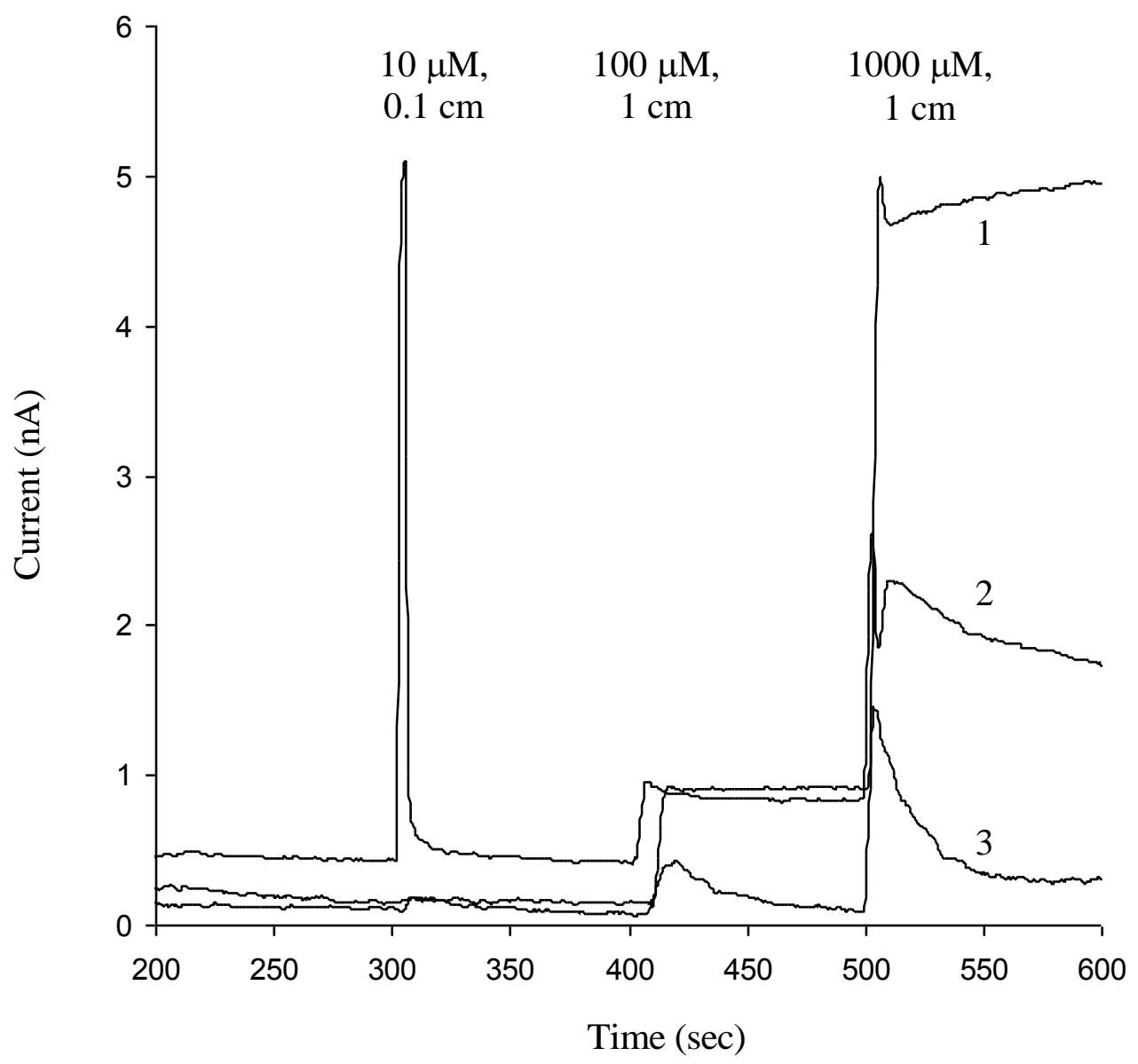


Figure 5

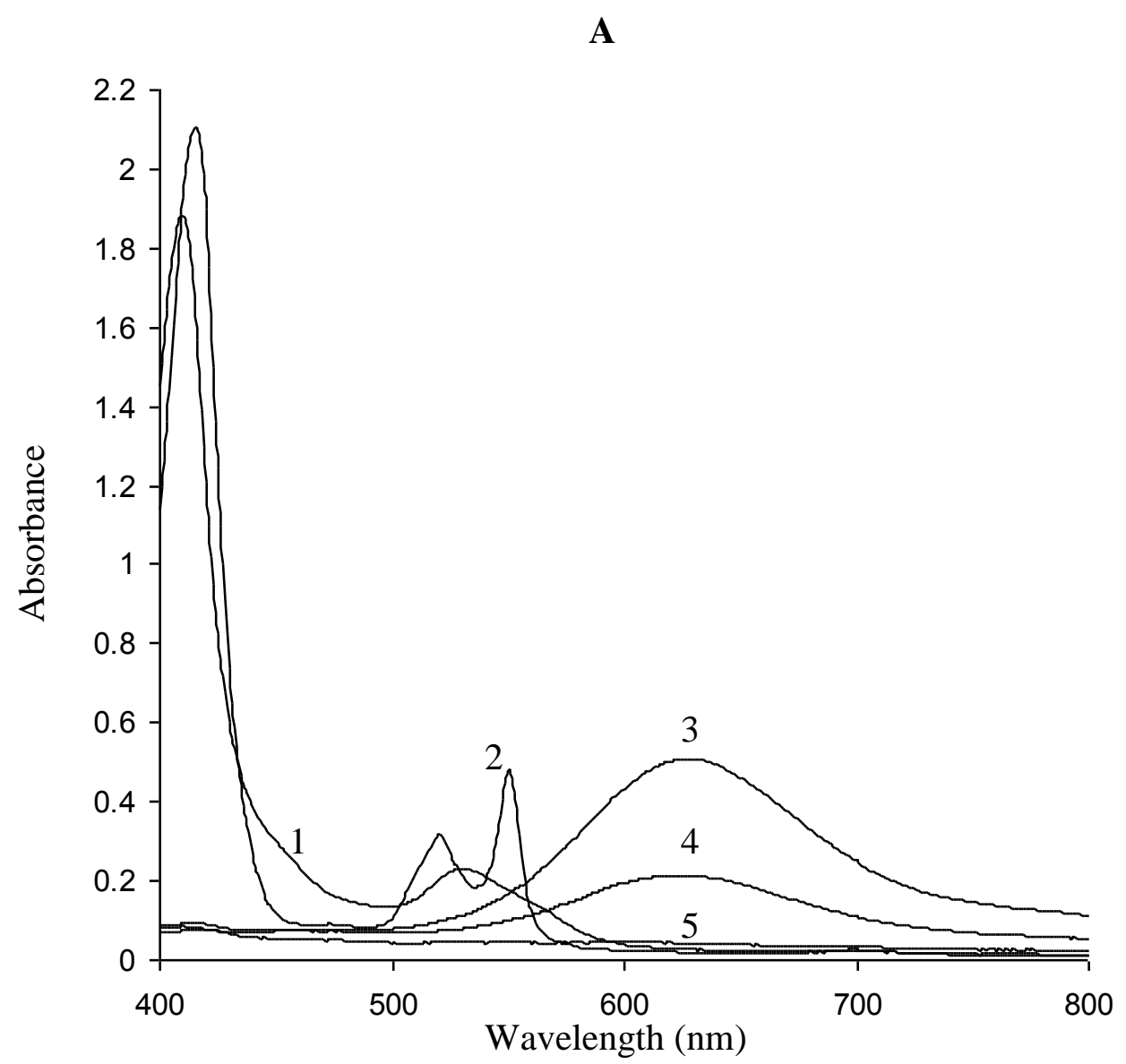

B

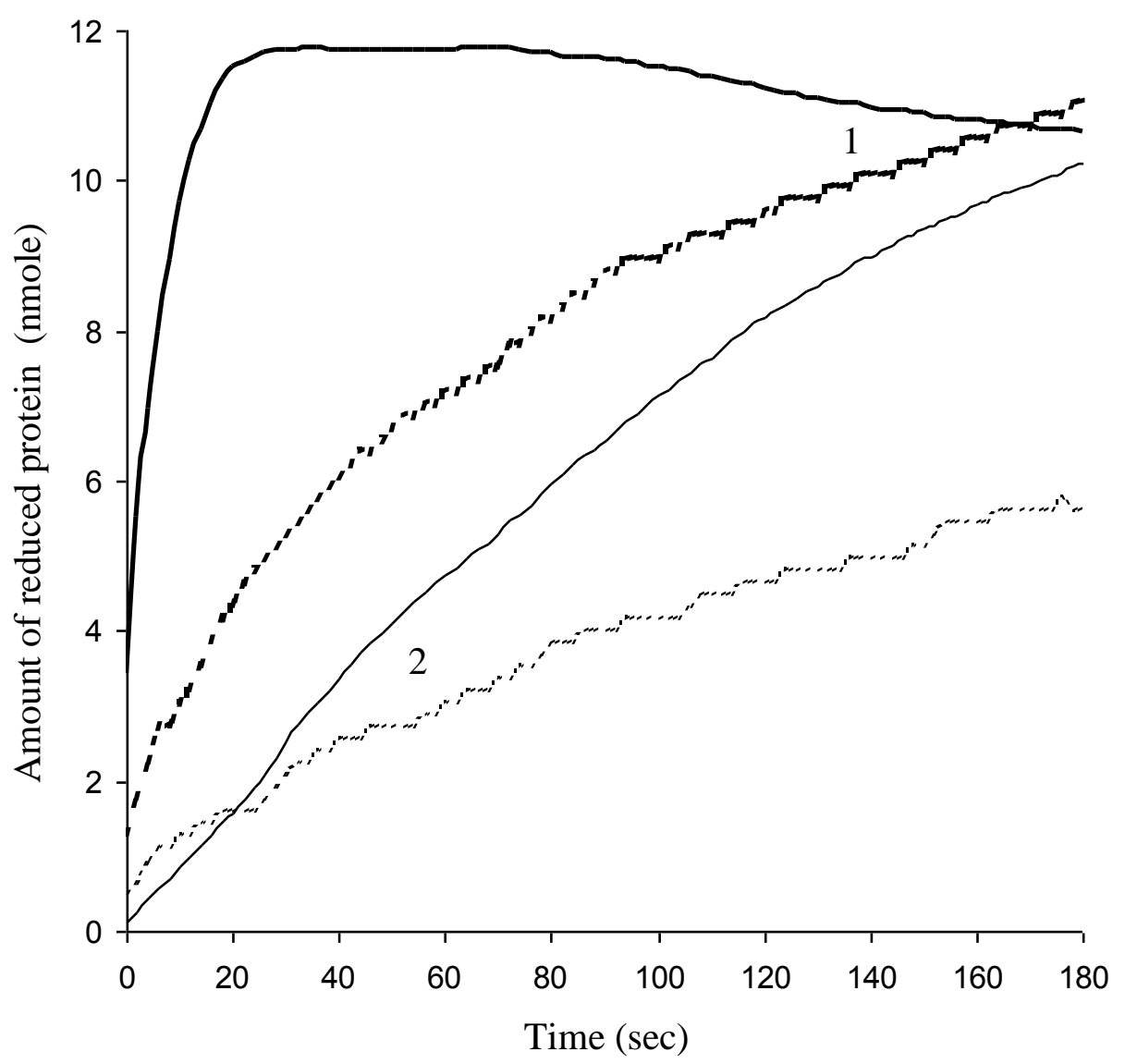


Figure 6
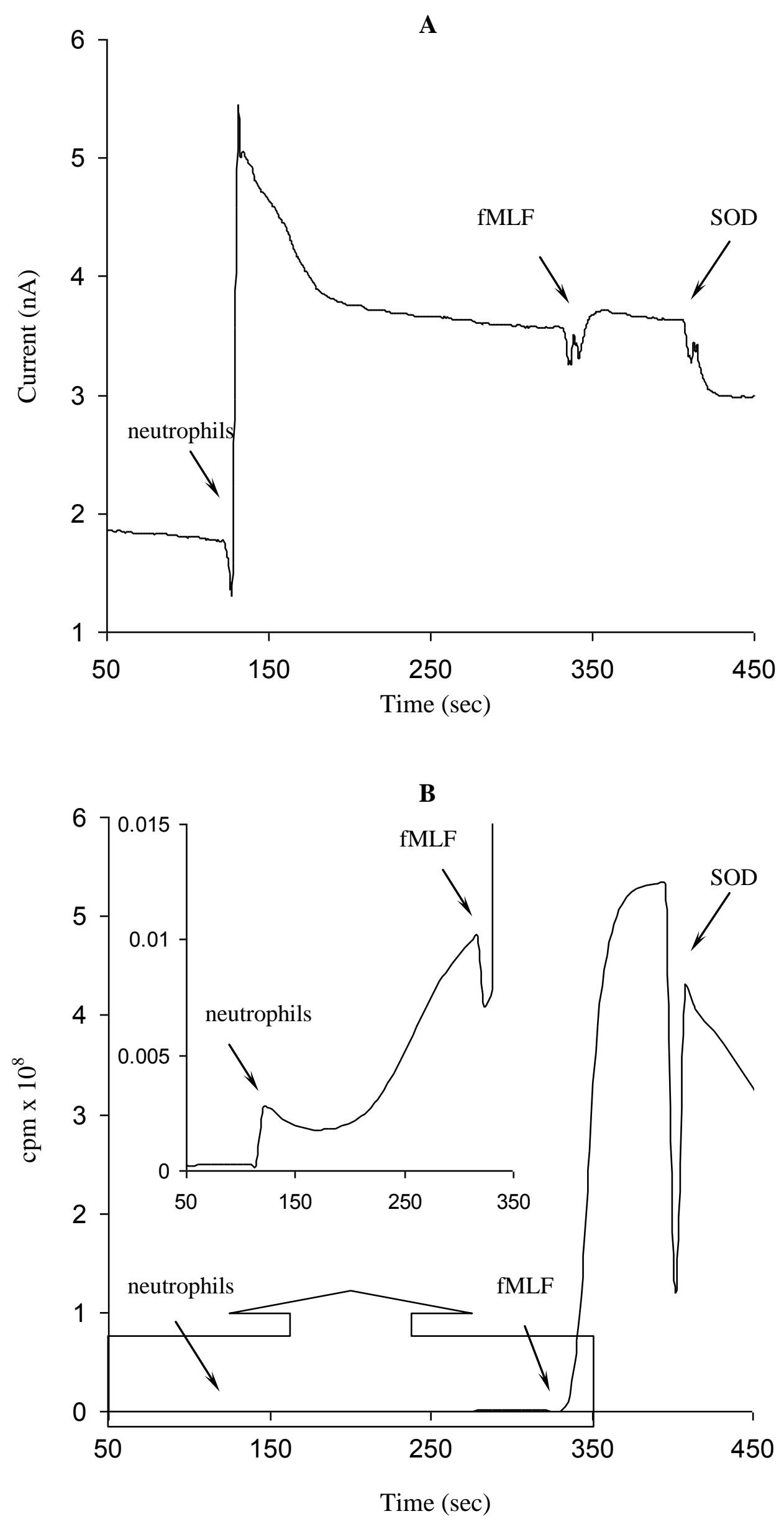